\title{
PENGARUH MODEL PROBLEM BASED LEARNING(PBL) TERHADAP KEMAMPUAN PEMECAHAN MASALAH PESERTA DIDIK PADA MATA PELAJARAN BIOLOGI MATERI PENCEMARAN LINGKUNGAN KELAS X MIA SMA N 6 BANDAR LAMPUNG
}

\section{${ }^{1}$ Dwijowati Asih Saputri, ${ }^{2}$ Selfy febriani}

1) Dosen Prodi Pendidikan Biologi Fakultas Tarbiyah dan Keguruan UIN Raden Intan Lampung

2) Mahasiswa Pendidikan Biologi Fakultas Tarbiyah dan Keguruan UIN Raden Intan Lampung JL. Let. Kol. H. Endro Suratmin Sukarame Bandar Lampung. Telp. (0721) 780887

Diterima: 29 Mei 2017. Disetujui : 19 Juni 2017. Dipublikasikan: 29 Juni 2017

\begin{abstract}
Abstrak:Salah satu tujuan dari model pembelajaran Problem Based Learning (PBL) adalah untuk meningkatkan kemampuan pemecahan masalah peserta didik agar dapat menjadi Sumber Daya Manusia (SDM) yang berkualitas.Tujuan penelitian ini adalah untuk mengetahui pengaruh model Problem Based Learning (PBL) terhadap kemampuan pemecahan masalah peserta didik pada materi pencemaran lingkungan kelas X MIA semester ganjil di SMA Negeri 6 Bandar Lampung.
\end{abstract}

Metode yang digunakan dalam penelitian ini adalah quasi eksperimen. menggunakan Nonequivalent control group designartinya adalah desain yang dimana terdapat 2 kelompok yang dipilih secara random, kemudian diberi pretest untuk mengetahui keadaan awal adakah perbedaan antara kelompok eksperimen dan kelompok kontrol. Jumlah populasi peserta didik X MIA adalah 129 peserta didik, yang kemudian 2 kelas merupakan sampel yaitu kelas X MIA 1 berjumlah 32 peserta didik sebagai kelas eksperimen dan X MIA 2 berjumlah 33 peserta didik sebagai kelas kontrol.

Berdasarkan hasil analisis data penelitian menunjukkan bahwa nilai rata-rata pretestpada kelas eksperimen adalah 42,09 , sedangkan rata-rata posttestnya adalah 74,68 . Pada kelas kontrol nilai rata-rata pretest 44,18 dan nilai posttestdengan ratarata 63,24. Hasil uji $t$ menunjukkan $t_{\text {hitung }}>t_{\text {tabel }}(2,42>1,98)$ hal tersebut menunjukan bahwa $\mathrm{H}_{0}$ ditolak dan $\mathrm{H}_{1}$ diterima. Jadi, dapat disimpulkan bahwa model Problem Based Learning (PBL) berpengaruh signifikan terhadap kemampuan pemecahan masalah peserta didik pada mata biologi materi pencemaran lingkungan kelas X MIA SMA N 6 Bandar Lampung.

Kata Kunci : Model Problem Based Learning (PBL), Kemampuan Pemecahan Masalah

\section{PENDAHULUAN}

Pendidikan merupakan pengubahan sikap dan tata laku seseorang atau kelompok orang dalam hal mendewasakan manusia melalui upaya pengajaran dan pelatihan. Pendidikan merupakan suatu kebutuhan yang harus dipenuhi dalam proses kehidupan. Majunya suatu bangsa dipengaruhi oleh mutu pendidikan dari 
bangsa itu sendiri karena pendidikan yang tinggi dapat mencetak Sumber Daya Manusia (SDM) yang berkualitas. Pendidikan yang dimaksud bukan bersifat informal melainkan bersifat formal meliputi proses belajar mengajar yang melibatkan guru dan peserta didik di sekolah.

Fakta ini secara tidak langsung menuntut adanya Sumber Daya Manusia (SDM) yang memliki kemampuan dan keterampilan dalam memecahkan masalah. Untuk itu, kemampuan dan keterampilan dalam memecahkan masalah perlu ditanamkan sedini mungkin terutama di dunia pendidikan.

Masyarakat yang dinamis akan selalu mengalami perkembangan, selalu menuntut adanya perubahan sesuai dengan perkembangan zaman. Pada hakikatnya, hal itu pun dapat dipandang sebagai akibat sistem pendidikan yang dijalankan yang juga sudah diperhitungkan. Dengan kata lain, adanya keadaan masyarakat yang dinamis dan terbuka terhadap adanya usaha-usaha pembaharuan sesuai dengan perkembangan zaman tersebut, merupakan keberhasilan sistem pendidikan tanpa mengabaikan berbagai faktor lain yang juga berperan. ${ }^{1}$

Pada dasarnya program pembelajaran bertujuan tidak hanya memahami dan menguasai apa dan bagaimana suatu terjadi, tetapi juga memberi pemahaman dan penguasaan tentang "mengapa hal itu terjadi". Berpijak pada permasalahan tersebut, maka pembelajaran pemecahan masalah menjadi sangat penting untuk diajarkan. $^{2}$

Program pembelajaran menggunakan kurikulum 2013 menuntut perubahan mindset pada diri guru agar lebih mengaktifkan peserta didik dengan menerapkan pendekatan saintifik, yang tujuannya untuk meningkatkan kemampuan berpikir tingkat tinggi seperti menganalisis, membandingkan, menalar, mengasosiasi, dan menyimpulkan. Melalui langkah-langkah saintifik inilah diharapkan kemampuan berpikir tingkat tinggi peserta didik akan berkembang seperti kemampuan mengamati, menanya/mempertanyakan, menalar, mencoba, mengumpulkan informasi, menganalisis, dan mengomunikasikan.

Perubahan paradigma pendidikan yang lebih mengaktifkan peserta didik sebagai subyek belajar, kondisi ini harus menjadi perhatian para guru. Bagaimana mengaktifkan peserta didik sekaligus meningkatkan level kemampuan berpikir secara terus-menerus hingga ke tingkat yang lebih tinggi, apalagi kalau kita kaitkan dengan tuntutan mampu berpikir kritis dan kreatif dalam menghadapi berbagai masalah. Perlunya peserta didik Sekolah Menengah Atas (SMA) mempunyai kemampuan berpikir tingkat tinggi dan pemecahan masalah, secara eksplisit telah dirumuskan dalam Permendikbud No.64, tahun 2013 tentang kompetensi kelas X pada Kurikulum 2013 (K13) untuk mata pelajaran biologi SMA-MA (Permendikbud, 2013) ${ }^{3}$

Pandangan pemikir pendidikan Internasional pun, memecahkan masalah itu dipandang urgen bagi para lulusan SMA pada abad pengetahuan (abad ke21).Pada era globalisasi seperti saat ini, dibutuhkan sumber daya manusia yang berkualitas dan dapat mengatasi berbagai masalah hidup yang semakin kompleks,

\footnotetext{
1 Burhan Nurgianto, Dasar-Dasar Pengembangan Kurikulum Sekolah. (Yogyakarta: BPFE-Yogyakarta, 2008) h. 2

${ }^{2}$ Made Wena, Strategi Pembelajaran Inovatif Kontemporer (suatu tinjauan konseptual operasional), (Jakarta: Bumi Aksara, 2012), h.52

${ }^{3}$ Peraturan Menteri Pendidikan dan Kebudayaan No.64 Tahun 2013 tentang Standar Isi Pendidikan Dasar dan Menengah. h.67
} 
Pendidikan merupakan salah satu modal utama bagi suatu bangsa dalam meningkatkan kualitas sumber daya manusia tersebut.Biologi adalah salah satu mata pelajaran di sekolah yang dapat digunakan bertujuan untuk mencetak sumber daya manusia yang berkualitas.

Pembelajaran sains biologi dengan menggunakan model pembelajaran Problem Based Learning (PBL) menekankan pada berpikir tingkat tinggi.Peserta didik harus berusaha belajar mandri dalam memecahkan problem dengan mengembangkan kemampuan menganalisis dan mngelola informasi. Oleh sebab itu, hasil belajar dari model pembelajaran Problem Based Learning (PBL) adalah peserta didik memiliki keterampilan penyelidikan, dan akan memperoleh pengalaman belajar yang berhubungan dengan keterampilan dalam pemecahan masalah. ${ }^{4}$

Menurut Tan Problem Based Learning (PBL) merupakan inovasi dalam pembelajaran karena dalam PBL kemampuan berfikir peserta didik betul-betul dioptimalisasikan melalui proses kerja kelompok atau tim yang sistematis, sehingga peserta didik dapat memberdayakan, mengasah, menguji, dan mengembangkan kemampuan berfikirnya secara berkesinambungan. Pada kenyataannya, tidak semua guru memahami Konsep Problem Based Learning (PBL) tersebut, baik disebabkan oleh kurangnya keinginan dan motivasi untuk meningkatkan kualitas keilmuan maupun karena kurangnya dukungan sistem untuk meningkatkan kualitas keilmuan tenaga pendidik. ${ }^{5}$

Salah satu tujuan dari model pembelajaran Problem Based Learning (PBL) adalah untuk meningkatkan kemampuan pemecahan masalah peserta didik agar dapat menjadi Sumber Daya Manusia (SDM) yang berkualitas. Robert S. Solso menjelaskan bahwa memecahkan masalah adalah suatu pemikiran yang terarah secara langsung untuk menemukan suatu solusi/ jalan keluar untuk suatu masalah yang spesifik. ${ }^{6}$

Kemampuan pemecahan masalah sangat penting bagi peserta didik, karena peserta didik akan dihadapkan pada permasalahan yang tidak dapat secara langsung ditemukan penyelesaiannya, baik masalah yang terdapat di dalam kelas maupun yang terdapat dalam kehidupan sehari-hari peserta didik. Namun kenyataannya, pelaksanaan pendidikan saat ini guru hanya menekankan pada penguasaan konsep.

Peserta didik dianggap telah menguasai konsep pembelajaran apabila telah mencapai standar nilai tertentu. Akibatnya, peserta didik hanya menghafal konsep yang diberikan agar memperoleh nilai tinggi pada saat ujian. Proses pembelajaran yangdemikian akan menghambatpengembangan kemampuan pemecahan masalah peserta didik.

Berdasarkan hasil observasi di SMAN 6 Bandar Lampung pada guru mata pelajaran biologi diketahui bahwa sistem pengajaran biologi secara alami mengarah kepada model pembelajaran langsung (Direct Instruction). Guru lebih banyak menyampaikan materi dengan sistem pembelajaran yang membuat peserta didik kurang aktif dalam pembelajaran sehingga pada akhirnya nilai hasil belajar

\footnotetext{
${ }^{4}$ Agus Suprijono, Cooperative Learning, (Yogyakarta: Pustaka Pelajar, 2015), h.89-91

${ }^{5}$ Rusman, Model-model Pembelajaran Mengembangkan Profesionalisme Guru, (Jakarta: Raja grafindo Persada, 2011), h. 229

${ }^{6}$ Robert L. Solso, Otto H. Maclin, M. Kimberly Maclin, Psikologi Kognitif, terjemahan Mikael Rahardato dan Kristianto Bajuadji (Jakarta : Erlangga, 2008), h. 434
} 
yang didapatkan menjadi kurang maksimal. Hal ini dapat dilihat dari nilai hasil ulangan harian (nilai kognitif) yang diperoleh peserta didik tahun ajaran 2016/2017 berikut :

\section{Tabel 1. Data Nilai Ulangan Harian Peserta didik Kelas X MIA SMA N 6} Bandar LampungTahun Ajaran 2016/2017

\begin{tabular}{|c|c|c|c|c|c|c|c|}
\hline \multirow{2}{*}{ No } & \multirow{2}{*}{$\begin{array}{c}\text { Nilai } \\
\text { Kognitif }\end{array}$} & \multicolumn{4}{|c|}{ Kelas X MIA } & \multirow{2}{*}{ Jumlah } & \multirow{2}{*}{$\begin{array}{c}\text { Presentase } \\
(\%)\end{array}$} \\
\hline & & X MIA 1 & X MIA 2 & X MIA 3 & X MIA 4 & & \\
\hline 1 & $81-100$ & - & 1 & - & 2 & 3 & $2,32 \%$ \\
\hline 2 & $72-80$ & 9 & 1 & 1 & 7 & 18 & $13,95 \%$ \\
\hline 3 & $60-71$ & 11 & 15 & 9 & 10 & 45 & $34,88 \%$ \\
\hline 4 & $40-59$ & 7 & 9 & 15 & 8 & 39 & $30,28 \%$ \\
\hline 5 & $00-39$ & 5 & 7 & 7 & 5 & 24 & $18,60 \%$ \\
\hline \multicolumn{2}{|c|}{$\begin{array}{c}\text { Jumlah Peserta } \\
\text { Didik }\end{array}$} & 32 & 33 & 32 & 32 & 129 & $100 \%$ \\
\hline
\end{tabular}

Tabel di atas menunjukkan bahwa nilai kognitif peserta didik masih kurang maksimal bahkan bisa dibilang rendah, karena nilai yang dicapai peserta didik sebagian tidak mencapai Kriteria Ketuntasan Minimal (KKM). Kriteria Ketuntasan Minimal (KKM) untuk pelajaran Biologi di SMA Negeri 6 Bandar Lampung adalah 72, berdasarkan tabel dapat terlihat bahwa peserta didik yang memenuhi Kriteria Ketuntasan Minimal (KKM) hanya 21 peserta didik atau 16,27\% sedangkan, peserta didik yang di bawah Kriteria Ketuntasan Minimal (KKM) adalah 108 peserta didik atau 83,73\%. Ini menunjukan bahwa hasil belajar pada ranah kognitif peserta didik masih rendah.

Hasil wawancara dengan ibu Nurlia guru Biologi di SMA Negeri 6 Bandar Lampung tanggal 25 januari 2016, juga menunjukkan bahwa hasil belajar menggunakan cara pembelajarannya selama ini masih belum maksimal, menurut penulis hal ini disebabkan karena proses pembelajaran belum menggunakan model pembelajaran yang tepat. Selama ini guru menerapkan metode konvensional yaitu mengarah kepada model pembelajaran langsung (Direct Instruction) di dalam kegiatan pembelajaran.

Model pembelajaran langsung ini menjadikan guru sebagai pusat dari proses kegiatan di kelas, guru lebih aktif memberi informasi dapat berbentuk ceramah dan pelatihan atau praktik. ${ }^{7}$ Dalam model pembelajaran ini menunjukan bahwa guru berperan aktif, lebih banyak melakukan aktivitas dibandingkan peserta didiknya, sedangkan peserta didiknya berperan lebih pasif tanpa banyak melakukan pengolahan bahan, karena menerima bahan ajaran yang disampaikan guru.

Pembelajaran dengan model pembelajaran langsung yang dilakukan di sekolah tidak meningkatkan kemampuan pemecahan masalah dari peserta didik karena aktivitas pembelajaran yang dilakukan oleh peserta didik terbatas oleh buku teks.Sementara diskusi kelompok yang dilakukan biasanya kurang memfasilitasi pengembangan kemampuan pemecahan masalah oleh peserta didik karena persoalan yang didiskusikan tidak bercirikan masalah dan jawaban dari persoalan tersebut telah tersedia dalam buku teks yang dimiliki peserta

\footnotetext{
${ }^{7}$ Trianto,Mendesain Model Pembelajaran Inovatif, Progrsif dan Kontekstual. (Yogyakarta, PT. Kencana, 2014). h.95
} 
didik.Pembelajaran dengan model pembelajaran langsung masih bersifat teacher center yang cenderung berpusat pada guru.

Berdasarkan rendahnya hasil belajar ini, guru diharapkan untuk menerapkan model pembelajaran yang tepat selama proses pembelajaran sehingga diharapkan nilai hasil belajar dan kemampuan pemecahan masalah peserta didik dapat meningkat. Dari penjelasan tersebut penulis merasa perlu untuk mengadakan penelitian mengenai pengaruh model pembelajaran Problem Based Learning (PBL) terhadap kemampuan pemecahan masalah peserta didik kelas X MIA SMA Negeri 6 Bandar Lampung Tahun Ajaran 2016/2017 pada mata pelajaran biologi materi pencemaran lingkungan

\section{METODE PENELITIAN}

Jenis penelitian ini adalah penelitian eksperimental (Quasi Eksperimen). ${ }^{8}$ Sifat penelitian ini adalah penelitian kuantitati, menggunakan Nonequivalent control group design. Penelitian ini menggunakan terdapat 2 kelompok yang dipilih secara random, kemudian diberi pretest untuk mengetahui keadaan awal adakah perbedaan antara kelompok eksperimen dan kelompok kontrol. Setelah perlakuan selanjutnya posttest diberikan pada kedua kelompok tersebut untuk melihat keadaan akhir dari peserta didik. Pada kelas eksperimen yaitu pada kelas $\mathrm{X}$ MIA 1 dengan menggunakan model pembelajaran Problem Based Learning (PBL), sedangkan pada kelas kontrol yaitu kelas X MIA 2 menggunakan model pembelajaran Direct Instruction (DI).

Penelitian ini dilaksanakan pada tahun 2016, bertempat di SMA Negeri 6 Bandar Lampung, kelas X MIA semester ganjil tahun pelajaran 2016/2017. Populasi dalam penelitian ini adalah seluruh peserta didik kelas X MIA di SMA Negeri 6 Bandar Lampung yang terdiri dari 4 kelas dan jumlah peserta didik berjumlah 129 peserta didik.

Teknik sampling yang akan digunakan dalam pengambilan kelas eksperimen dan kelas kontrol adalah Probability Sampling.Tehnik samplingdilakukandengan secara acak dengan cara melakukan undian pada semua kelas $\mathrm{X}$ untuk menentukan kelas yang akan digunakan sebagai kelas eksperimen dan kelas kontrol . ${ }^{9}$ Dari undian tesebut di peroleh sampel untuk kelas eksperimen adalah X MIA 1 dengan jumlah peserta didik sebanyak 32 orang yang dalam kegiatan belajar mengajarnya menerapkan model pembelajaran Problem Based Learning (PBL) dan kelas X MIA 2 dengan jumlah peserta didik 33 orang yang akan menjadi kelas kontrol dan dalam pembelajarannya menggunakan model pembelajaran Direct Instruction (DI).

Instrumen pada penelitaian ini berupa tes.Tes digunakan dalam penelitian bertujuan untuk melihat dan mengukur tingkat kemampuan pemecahan masalah peserta didik. Pada penelitian ini tes yang diberikan berbentuk essay dengan jumlah soal tes yang diberikan yaitu 15 item soal, dimana masing-masing soal memiliki skor sendiri sesuai dengan indikator kemampuan pemecahan masalah. Tes yang diberikan pada penelitian ini yaitu tentang materi pencemaran lingkungan air. Ada 2 tes yang di gunakan pada penelitian ini yaitu :

1) Memberikan tes kemampuan awal (pretest) tentang konsep pencemaran lingkungan air di kedua kelas tersebut.

\footnotetext{
${ }^{8}$ Margono, Metodologi Penelitian Pendidikan, (Jakarta : Rineka Cipta, 2010), h. 110

${ }^{9} \mathrm{Ibid}$, h. 124
} 
2) Memberikan tes kemampuan akhir (posttest) tentang konsep pencemaran lingkungan air di kedua kelas eksperimen dengan soal yang sama.

Pengujian instrumen dilakukan untuk mengetahui validitas, reliabilitas, tingkat kesukaran dan daya beda dari insrumen tersebut. Tes yang akan diberikan merupakan tes objektif berbentuk essay, yang terdiri dari 15 butir soal. Tes tersebut terdiri dari soal-soal materi pencemaran lingkungan.

Jenis validitas pada penelitian ini menggunakan validitas isi dan validitas konstruk (Content Validity and Construk Validity). Validitas isi adalah pengujian validitas untuk memastikan tes hasil belajar dapat mengukur secara tepat keadaan yang ingin diukur. ${ }^{10}$ Sedangkan, validitas konstruk adalah pengujian validitas yang dilakukan dengan melihat kesesuaian konstruksi butir yang ditulis dengan kisikisinya dimana hasil belajar dikonstruksi oleh sejumlah ranah. ${ }^{11}$

Tujuan dari uji reliabilitas adalah untuk mengetahui konsisten dari instrumen sebagai alat ukur, sehingga hasil pengukuran dapat dipercaya, apabila dalam beberapa kali pelaksanaan pengukuran terhadap kelompok subjek yang homogen diperoleh hasil yang relatif sama. Formula yang dipergunakan untuk menguji reliabilitas instrumen dalam penelitian adalah Cronbach Alpha. ${ }^{12}$ Uji Tingkat Kesukaran di lakukan untuk mendapatkan soal yang baik.Soal yang baik adalah soal yang tidak terlalu mudah dan juga tidak terlalu sukar.Sedangkan uji daya beda bertujuan untuk menganalisis daya pembeda artinya mengkaji soal-soal tes dari segi kesanggupan tes tersebut dalam membedakan peserta didik yang termasuk ke dalam kategori lemah/ rendah dan kategori kuat/ tinggi prestasinya.

Sesuai dengan tujuan penelitian yaitu untuk mengetahui pengaruh model pembelajaran Problem Based Learning (PBL) terhadap kemampuan pemecahan masalah peserta didik kelas X MIA, maka hipotesis hasil penelitian ini akan diuji menggunakan Uji-t, setelah dilaksanakan uji prasarat terhadap hasil penelitian yang diperoleh. Uji prasarat tersebut meliputi uji normalitas data dan uji homogenitas data. Uji normalitas dengan metode liliefors, karena uji ini digunakan untuk normalitas data yang kecil dan tidak perlu dikelompokkan. Sedangkan Uji homogenitas yang digunakan pada data hasil penalitian ini adalah uji homogenitas dua varians atau uji fisher". ${ }^{13}$

\section{HASIL DANPEMBAHASAN}

Data yang diperoleh berupa nilai tes kemampuan pemecahan masalah yang sebelumnya melakukan telah melewati hasil uji coba yang terdiri dari 10 butir soal essay pada populasi di luar sampel penelitian. Uji coba tes dilakukan pada 30 peserta didik kelas XI IPA 1 SMA N 6 Bandar Lampung. Data hasil uji coba tersebut dianalisis untuk mengetahui karakteristik setiap butir soal yang meliputi validitas, tingkat kesukaran, daya pembeda dan reliabilitasnya.

Berdasarkan data yang terkumpul dari 30 responden (peserta didik kelas XI IPA 1). dari 15 item pertanyaan 5 item soal yang tidak valid ada 5 item pertanyaan yakni item nomor 1, 2, 3,10 dan 13 item dan sisanya adalah valid.

\footnotetext{
${ }^{10}$ Purwanto, Evaluasi Hasil Belajar, (Yogyakarta : Pustaka Belajar, 2014) h. 120

${ }^{11}$ Ibid, h. 127-128

${ }^{12}$ Novalia, Muhamad Syazali, Olah Data Penelitian Pendidikan, (Bandar Lampung : Anugrah Utama Raharja (AURA), 2014), h. 39

${ }^{13}$ Daryanto, Evaluasi Pendidikan, (Jakarta : Rineka Cipta, 2010), h.249
} 
Dengan demikian, item yang tidak valid tersebut digugurkan dan tidak dapat digunakan pada analisis data penelitian.

Item-item instrumen soal yang telah valid kemudian diuji menggunakan uji reliabilitas.Hasil perhitungan menunjukkan bahwa item-item instrumen soal yang valid tersebut memiliki indeks reliabilitas sebesar0,723. Uji selanjutnya adalah uji tingkat kesukaran.Hasil uji tingkat kesukaranmenunjukkan bahwa 2 soal dengan kriteria mudah dan 13 soal kriteria sedang., soal dengan berkriteria sedang merupakan soal yang baik sedangkan soal dengan kriteria mudah dianggap bukanlah soal yang baik. Maka dari itu pada penelitian ini soal yang sedang digunakan untuk penelitian sedangkan yang mudah tidak digunakan. Sedangkan Hasil Uji daya pembeda butir soal menunjukkan bahwa,dari 15 soal yang akan digunakan, 3 soal memiliki kriteria yang jelek sehingga ditolak untuk digunakan dalam penelitian.

Setelah dilakukan uji reliabilitas, uji validitas, uji tingkat kesukaran dan daya pembeda pada butir soal soal untuk pretest dan postest kemampuan pemecahan masalah, dari 15 soal yang diuji terdapat 10 soal essay yang memenuhi kriteria dan dapat digunakan dalam penelitian. Butir soal tes kemampuan pemecahan masalah yang dapat digunakan dalam penelitian ini antara lain nomor: 4, 5, 6, 7, 8, 9, 11, 12, 14 dan 15 .

Hasil uji prasarat sebelum dilakukan uji hipotesis adalah uji Nornalitas dan uji Homogenitas serta Normalitas N-Gain.Pengujian uji normalitas dilakukan terhadap data nilai pretest dan posttest dari setiap kelas, yaitu data nilai pretest dan posttestkelas X MIA 1 sebagai kelas eksperimen dan data nilai pretest dan posttest kelas X MIA 2 sebagai kelas kontrol. Untuk menguji normalitas kedua kelas tersebut, data digunakan rumus Uji Liliefors.

Hasil pengujian normalitas terhadap nilai pretest, posttest dan $\mathrm{N}$-gain baik pada kelas eksperimen maupun kelas kontrol, didapatkan hasil bahwa semua data berdistribusi normal. Hasil dari uji normalitas N-gain di kelas eksperimen maupn di kelas kontrol dinyatakan berdistribusi normal Uji normalitas $\mathrm{N}$-gain digunakan sebagai prasyarat yang pertama dalam menentukan uji hipotesis (uji t N-gain) yang akan dilakukan.

Pengujian homogenitas terhadap kedua data menggunakan uji fisher.Hasil perhitungan homogenitas data pretest, posttest baik pada kelas eksperimen maupun kontrol, didapatkan bahwa data dari ketiga kelas memiliki varians yang homogen.

\section{Analisis Setiap Indikator Kemampuan Pemecahan Masalah}

Hasil kemampuan pemecahan masalah yang diukur dalam penelitian ini difokuskan pada 5 indikator menurut David Johnson \& Johnson dalam buku Wina Sanjaya. Setiap indikator kemampuan pemecahan masalah dinilai oleh satu atau lebih soal berbentuk essay.Perolehan skor rerata pretest dan posttest pada setiap indikator kemampuan pemecahan masalah peserta didik kelas eksperimen dan kelas kontrol dapat dilihat pada tabel 4.8 dan tabel 4.9.

Tabel 2. Rerata Skor Pretest dan Posttest Hasil Kemampuan Pemecahan MasalahPerindikator pada Kelas Eksperimen

\begin{tabular}{|l|c|c|c|c|c|}
\hline \multirow{2}{*}{ Keterangan } & \multicolumn{5}{|c|}{ Indikator Pencapaian Materi*) } \\
\cline { 2 - 6 } & 1 & 2 & 3 & 4 & 5 \\
\hline Jumlah skor Pretest & 86 & 43 & 62 & 62 & 25 \\
\hline
\end{tabular}




\begin{tabular}{|l|c|c|c|c|c|}
\hline Jumlah skor Posttest & 102 & 115 & 110 & 90 & 80 \\
\hline N-gain & 1,13 & 1,26 & 1,25 & 0,74 & 0,73 \\
\hline Kategori & Tinggi & Tinggi & tinggi & Tinggi & tinggi \\
\hline
\end{tabular}

Tabel 3. Rerata Skor Pretest dan Posttest Hasil Kemampuan Pemecahan MasalahPerindikator pada Kelas Kontrol

\begin{tabular}{|l|c|c|c|c|c|}
\hline \multirow{2}{*}{ Keterangan } & \multicolumn{5}{|c|}{ Indikator Pencapaian Materi*) } \\
\cline { 2 - 6 } & 1 & 2 & 3 & 4 & 5 \\
\hline Jumlah skor Pretest & 76 & 47 & 65 & 53 & 49 \\
\hline Jumlah skor Posttest & 96 & 89 & 91 & 79 & 73 \\
\hline N-gain & 0,83 & 0,79 & 0.74 & 0,54 & 0,46 \\
\hline Kategori & Tinggi & Tinggi & Tinggi & Sedang & Sedang \\
\hline
\end{tabular}

*) Keterangan Indikator Pencapaian Materi :

1. Peserta didik dapat mengidentifikasi pokok masalah yang ada pada artikel pencemaran air

2. Peserta didik dapat mengdiagnosis penyebab terjadinya pencemaran air

3. Peserta didik dapat merumuskan alternatif strategi untuk memecahkan masalah

4. Peserta didik dapat menentukan alternatif strategi untuk memecahkan masalah

5. Peserta didik dapat mengevaluasi keberhasilan strategi untuk memecahkan masalah

\section{Analisis Uji Hipotesis}

Pengujian hipotesis ini dilakukan untuk mengetahui adanya pengaruh model pembelajaran Problem Based Learning (PBL) terhadap kemampuan pemecahan masalah peserta didik pada materi pencemaran lingkungan kelas X MIA SMA Negeri 6 Bandar Lampung. Setelah melakukan uji normalitas dan uji homogenitas, diketahui bahwa data pretest, posttest, dan $\mathrm{N}$-gain dari kedua kelas berdistribusi normal dan homogen.

Berdasarkan hasil perhitungan uji hipotesis diperoleh nilai N-gain hasil dari $t_{\text {hitung }}$ adalah 2,4253 dan $t_{\text {tabel }}$ dari hasil signifikasi 0,05 adalah 1,998 berarti bahwa $t_{\text {hitung }}>t_{\text {tabel }}$, sehingga $\mathrm{H}_{0}$ ditolak dan $\mathrm{H}_{1}$ diterima. Dengan demikian dapat disimpulkan bahwa kelas eksperimen pretest dan posttest terdapat pengaruh atau perbedaan yang signifikan model pembelajaran Problem Based Learning (PBL) terhadap kemampuan pemecahan masalah, begitu pula pada kelas kontrol pretest dan posttest terdapat perbedaan yang signifikan model pembelajaran Problem Based Learning (PBL) terhadap kemampuan pemecahan masalah peserta didik pada materi pencemaran lingkungan kelas X MIA SMA Negeri 6 Bandar Lampung.

Maka dengan demikian, dapat disimpulkan bahwa hasil pretest dan posttest pada kelas eksperimen terdapat pengaruh dan meningkat dalam penerapan model pembelajaran Problem Based Learning (PBL) terhadap kemampuan pemecahan masalah peserta didik pada materi pencemaran lingkungan kelas X MIA SMA Negeri 6 Bandar Lampung. Sama halnya pada kelas ekspresimen, pada kelas kontrol pretest dan posttest terdapat terdapat pengaruh dan peningkatkan model pembelajaran Problem Based Learning (PBL) terhadap kemampuan pemecahan 
masalah walaupun tidak signifikan sebagaimana hasil tes peserta didik di kelas eksperimen.

\section{PEMBAHASAN}

Penelitian ini menggunakan dua variabel yang menjadi objek penelitian, model pembelajaran Problem Based Learning (PBL) dan kemampuan pemecahan masalah peserta didi. Tahapan pertama pada pembelajaran biologi menggunakan model Problem Based Learning (PBL) adalah memberikan pretest dan mengorganisasi peserta didik menjadi 5 kelompok. Perbedaan perlakuan dari kelas kontrol dan kelas eksperimen yaitu pada kelas eksperimen informasi tertulis berupa masalah yang diberikan sebelum kelas dimulai.Fokusnya adalah bagaimana peserta didik mengidentifikasikan isu pembelajaran sendiri untuk memecahkan masalah.Materi dan konsep yang relevan ditemukan oleh peserta didik sendiri.Pada kelas kontrol informasi pembelajaran dipresentasikan dan didiskusikan oleh guru sehingga peserta didik hanya mendengarkan penjelasan guru . ${ }^{14}$

Pertemuan kedua dan ketiga dikelas eksperimen guru mengorganisasikan peserta didik untuk meneliti dan membantu investigasi peserta didik terhadap informasi masalah yang telah diberikan sebelumnya. Peserta didik bertukar pikiran dan mengembangkan pengetahuannya mengenai pencemaran lingkungan kemudian memberikan solusi atas permasalahan. Setelah tiap kelompok mendapatkan solusi selanjutnya, peserta didik menganalisis dan mengevaluasi proses pemecahan dari masalah dengan mempresentasikan hasil diskusinya didepan kelas. Tahap terakhir dari pembelajaran adalah dengan memberikan posttest.

Hasil dari tes kemampuan pemecahan masalah, mengalami peningkatan hal tersebut didasari manfaat model pembelajaran Problem Based Learning (PBL) yaitu peserta didik menjadi lebih ingat dan meningkatkan pemahamannya atas materi pencemaran lingkungan karena pengetahuan itu didapatkan lebih dekat dengan kehidupan sehari-hari.Meningkatkan fokus pada pengetahuan yang relevan dan mendorong peserta didik untuk berfikir karena peserta didik tidak terburu-buru menyimpulkan, mencoba menemukan landasan argumennya, dan fakta-fata yang mendukung alasan.Nalar dari peserta didik dilatih dan kemampuan berpikir untuk memecahkan masalah ditingkatkan.Peserta didik menjadi tidak sekedar tahu, tapi juga dipikirkan.

\section{Kemampuan Pemecahan Masalah}

Berdasarkan hasil pretest dan posttest yang telah dilakukan pada kelas eksperimen dan kelas kontrol hasil yang diperoleh sangatlah berbeda, untuk kelas eksperimen rata-rata nilai posttest sebesar 74,68 dengan $\mathrm{N}$-gain 0,53 yang termasuk kategori sedang. Sedangkan pada kelas kontrol rata-rata nilai posttest sebesar 63,24 dengan $\mathrm{N}$-gain 0,34 dengan kategori sedang. Hal ini membuktikan bahwa perolehan hasil tes kemampuan pemecahan masalah peserta didik kelas eksperimen lebih tinggi dibandingkan kelas kontrol.Perbedaan yang signifikan

${ }^{14}$ M.Taufiq Amir, Inovasi Pendidikan Melalui Problem Based Learning, (Jakarta: Kencana) Prenada Media Group, 2009) h.23 
pada kelas eksperimen dan kelas kontrol disebabkan karena adanya penerapan model pembelajaran Problem Based Learning (PBL) pada kelas eksperimen.

Faktor penyebab perbedaan hasil tes kemampuan pemecahan masalah antara kelas eksperimen dan kelas kontrol di atas dikarenakan peserta didik yang berada dikelas ekperimen lebih memiliki kesiapan dalam memecahkan masalah. Fakta peningkatan ini didukung dengan hasil penelitian yang dilakukan oleh Utama Dewi yang menunjukkan bahwa model Problem Based Learning (PBL) mampu mengakomodasi kemampuan pemecahan masalah peserta didik. Jika dibandingkan dengan peserta didik yang belajar dengan model Direct Instructions (DI), tentu peserta didik yang belajar dengan model PBL akan lebih unggul. Hal tersebut bisa dikarenakan pada model Direct Instructions (DI), guru menyampaikan informasi langsung kepada peserta didik dengan menata waktu pelajaran untuk mencapai beberapa sasaran yang telah ditentukan dengan jelas seefisien mungkin. Pembelajaran yang bersifat teacher centered tentu akan mengurangi kesempatan peserta didik untuk mengasah kemampuan berpikir dan kemampuan pemecahan masalah. ${ }^{15}$

Peserta didik di kelas ekperimen lebih lebih aktif, peserta didik tidak merasa bosan saat pembelajaran berlangsung karena peneliti mengemas situasi pembelajaran menjadi menyenangkan. Peserta didik merasa termotivasi setelah diterapkan model Problem Based Learning (PBL), karena pada pembelajaran ini diberikan suatu wacana yang nantinya membutuhkan solusi yang dipecahkan bersama anggota kelompok. Peserta didik menjadi terpancing untuk belajar lebih lanjut dalam menyelesaikan masalah.Hal ini menjadikan peserta didik tertarik menyimak penjelasan dari rekannya, dan peserta didik menjadi lebih aktif dalam bertanya sehingga mereka mengetahui informasi-informasi baru dari kelompok lainnya. Fakta ini didukung dengan hasil penelitian yang dilakukan oleh Herman Dwi Surjono menunjukkan bahwa Problem Based Learning (PBL) lebih menekankan pada pertukaran pendapat dan berbagi pengalaman dalam pemecahan masalah. Peserta didik yang memiliki motivasi tinggi akan lebih tertarik untuk mengexplore pengetahuan dan berkeinginan untuk mengetahui suatu hal baru guna memecahkan masalah yang berhubungan dengan dunia nyata. ${ }^{16}$

Kelas kontrol memiliki hasil tes kemampuan pemecahan masalah yang lebih rendah dibandingkan kelas ekperimen menurut peneliti hal itu di sebabkan karena peserta didik tidak terbiasa melatih kemampuan pemecahan masalahnya. Hal ini sejalan dengan pendapat Sardiman bahwa dengan banyak latihan akan dapat mempertinggi kesanggupan memperoleh insight, yang dalam hal ini adalah kemampuan pemecahan masalah. ${ }^{17}$ Pembiasaan memberi masalah ke dalam proses pembelajaran diharapkan peserta didik dapat memecahkan masalah. Hal ini sejalan dengan pendapat Trianto yang menyatakan pembelajaran berdasarkan masalah adalah pembelajaran yang realistik dengan kehidupan peserta didik,

15 Utama Dewi, "Pengaruh Model PBL Terhadap Kemampuan Pemecahan Masalah Fisika Melalui Pengendalian Bakat Numerik siswa Smp", (Jurnal, Program Pascasarjana Universitas Pendidikan Ganesha, Jakarta, Vol.4, 2014) h. 8

${ }^{16}$ Herman Dwi Surjono."PengaruhProblem Based LearningTerhadap Hasil Belajar Ditinjau Dari Motivasi BelajarPLC Di SMK”.(Jurnal. Pascasarjana UNY, Vol.3, No.2, 2013) h.11

\footnotetext{
${ }^{17}$ Sardiman.Interaksi Dan Motivasi Belajar Mengajar. (Jakarta: Rajawali Pers, 2011), h.31
} 
pemberian konsep untuk menumbuhkan sikap inkuiri peserta didik dan memupuk kemampuan pemecahan masalah. ${ }^{18}$

Pada pembelajaran ini, N-gain hasil kemampuan pemecahan masalah yang meningkat paling tinggi di kelas eksperimen ada pada indikator mendiagnosis masalah, hal ini menandakan bahwa peserta didik di kelas eksperimen sangat baik dalam hal mendiagnosis masalah.Menurut Tri Utami Widayanti Problem Based Learning (PBL) dapat meningkatkan kemampuan memecahkan masalah karena PBL adalah model yang berorientasi pada masalah kehidupan nyata yang menuntut peserta didik mampu memecahkan masalah yang ada.Peserta didik dituntut untuk menggunakan kemampuan berpikirnya. ${ }^{19}$

Selanjutnya indikator dengan $\mathrm{N}$-gain terendah di kelas eksperimen berada pada indikator melakukan evaluasi keberhasilan strategi, artinya pada indikator ini sangat sedikit peserta didik yang mampu mengemukakan penilaian berupa kendala dan kemudahan dari solusi yang mereka tawarkan terhadap masalah pencemaran air.Hal ini disebabkan peserta didik belum terbiasa, kurang memupuk dan kurang melatih kemampuan pemecahan masalah mereka hingga ditahap pemikiran penilaian kendala dan kemudahan dari keberhasilan strategi. Dengan dibiasakannya pemberian masalah ke dalam proses pembelajaran diharapkan peserta didik dapat memecahkan masalah. Hal ini sejalan dengan pendapat Trianto yang menyatakan pembelajaran berdasarkan masalah adalah pembelajaran yang realistik dengan kehidupan peserta didik, pemberian konsep untuk menumbuhkan sikap inkuiri peserta didik dan memupuk kemampuan pemecahan masalah. $^{20}$

Kelas kontrol mengalami peningkatan $\mathrm{N}$-gain indikator kemampuan pemecahan masalah tertinggi pada indikator mengidentifikasi masalah, karena peserta didik dengan mudah mengidentifikasi masalah berdasarkan bacaan yang telah disiapkan.Pada kelas kontrol peserta didik tidak perlu mencari dan menemukan sendiri fakta-fakta, konsep dan prinsip karena telah disajikan secara jelas oleh guru. Nilai N-gain pada indikator yang paling rendah pada kelas kontrol sama dengan kelas eksperimen yaitu indikator melakukan evaluasi keberhasilan strategi. Hal ini terjadi karena dalam proses pembelajaran yang sangat pasif membuat indikator kemampuan evaluasi keberhasilan strategi juga tidak meningkat.Selama kegiatan pembelajaran berlangsung peserta didik hanya mendengarkan penjelasan dari guru dan hal tersebutlah yang membuat kemampuan pemecahan masalah peserta didik tidak meningkat signifikan.Hal ini sejalan dengan pendapat Kardi bahwa model pembelajaran langsung digunakan untuk menyampaikan pelajaran yang ditransformasikan langsung dari guru kepada peserta didik. $^{21}$

Pada kelas ekperimen terdapat 5 peserta didik memiliki peningkatan kemampuan pemecahan masalah dengan $\mathrm{N}$-gain yang tinggi dan tidak ada peserta didik berkategori tinggi pada kelas kontrol.Hal ini berarti sebanyak 5 peserta didik di kelas eksperimen tersebut mampu menyelesaikan masalah pencemaran air oleh

\footnotetext{
${ }^{18}$ Trianto.Model-Model Pembelajaran Inovatif Berorientasi Konstrutivistik.Jakarta: Prestasi Pustaka, 2010) h. 96

${ }^{19}$ Tri Utami Widayanti dkk.” Perbedaan KemampuanMemecahkan Masalah Dan Retensi Menggunakan Model PBL (Problem Based Learning)Dan Ceramah Bervariasi Pada

MateriKeanekaragaman Hayati”. (Jurnal.,Vol.4, No.1, FKIP USM, 2015) h. 3

${ }^{20}$ Trianto, Loc.cit.

${ }^{21}$ Ibid. h.95
} 
pabrik tahu dan kerupuk yang dapat dilihat dari kemampuan peserta didik mengidentifikasi dan mendiagnosis masalah, merumuskan alternatif strategi, menentukan dan menerapkan strategi pilihan serta melakukan evaluasi keberhasilan strategi.Tingginya skor kemampuan pemecahan masalah dikarenakan 5 peserta didik ini memiliki kesiapan dalam memecahkan masalah. Hal ini sejalan dengan pendapat Slameto bahwa kesiapan adalah kesediaan untuk memberi respon yang perlu diperhatikan dalam proses belajar, karena jika peserta didik belajar dan padanya sudah ada kesiapan, maka hasilnya akan lebih baik. ${ }^{22}$

Sebanyak 25 peserta didik di kelas ekperimen dan 22 peserta didik di kelas kontrol berada pada kategori sedang.Artinya, peserta didik tersebut hanya mampu menyelesaikan masalah pencemaran air oleh pabrik tahu dan kerupuk yang dapat dilihat dari kemampuan peserta didik mengidentifikasi dan mendiagnosis masalah, merumuskan alternatif strategi belum dapat menentukan menerapkan strategi pilihan yang sesuai dengan permasalahan serta melakukan evaluasi keberhasilan strategi. Hal ini disebabkan materi yang diangkat dalam pembelajaran berupa masalah yang autentik dan bermakna sehingga peserta didik mempunyai motif atau dorongan untuk menyelesaikannya. Hal ini sejalan dengan pendapat Slameto, dalam proses belajar haruslah diperhatikan apa yang dapat mendorong peserta didik agar dapat belajar dengan baik atau padanya mempunyai motif untuk berpikir dan memusatkan perhatian, merencanakan dan melaksanakan kegiatan yang berhubungan atau menunjang belajar.

Sebanyak 2 peserta didik kelas eksperimen dan 11 peserta didik di kelas kontrol berada pada kategori $\mathrm{N}$-gain yang rendah.Hal ini berarti ke 13 peserta didik tersebut tidak mampu menyelesaikan masalah.Rendahnya kemampuan pemecahan masalah dikarenakan peserta didik tidak terbiasa melatih kemampuan pemecahan masalahnya. Hal ini sejalan dengan pendapat Sardiman bahwa dengan banyak latihan akan dapat mempertinggi kesanggupan memperoleh insight, yang dalam hal ini adalah kemampuan pemecahan masalah. ${ }^{23}$

\section{DAFTAR PUSTAKA}

Agus Suprijono. Cooperative Learning. Surabaya : Pustaka Belajar, 2009.

Burhan Nugiantoro. Dasar-dasar Pengembangan Kurikulum Sekolah. Yogyakarta: BPFE-Yogyakarta, 2008.

Daryanto.Evaluasi Pendidikan.Jakarta : Rineka Cipta, 2010.

Herman Dwi Surjono."Pengaruh Problem Based Learning Terhadap Hasil Belajar Ditinjau Dari Motivasi Belajar PLC Di SMK".Jurnal. Pascasarjana UNY, Vol.3, No.2, Yogyakarta. 2013.

Made Wena.Strategi Pembelajaran Inovatif Kontemporer (suatu tinjauan konseptual operasional). Jakarta : Bumi Aksara, 2012.

Margono.Metodologi Penelitian Pendidikan. Jakarta : Rineka Cipta, 2010.

M.Taufiq Amir, Inovasi Pendidikan Melalui Problem Based Learning. Jakarta: Kencana Prenada Media Group. 2009.

Novalia dan Muhamad Syazali.Olah Data Penelitian Pendidikan. Bandar Lampung : Anugrah Utama Raharja (AURA), 2014.

${ }^{22}$ Slameto.Belajar Dan Faktor-Faktor Yang Mempengaruhi. (Jakarta: Rineka Cipta, 2003) h.

\footnotetext{
${ }^{23}$ Sardiman.Loc.Cit.
} 
Peraturan Menteri Pendidikan dan Kebudayaan No.64 Tahun 2013 tentang Standar Isi Pendidikan Dasar dan Menengah

Purwanto.Evaluasi Hasil Belajar. Yogyakarta : Pustaka Belajar, 2014.

Robert L. Solso, Otto H. Maclin, M. Kimberly Maclin. Psikologi Kognitif. terjemahan Mikael Rahardato dan Kristianto Bajuadji. Jakarta : Erlangga, 2008.

Rusman.Model-model Pembelajaran Mengembangkan Profesionalisme Guru. Jakarta : Raja grafindo Persada, 2011.

Sardiman.Interaksi Dan Motivasi Belajar Mengajar. Jakarta: Rajawali Pers, 2011. Slameto.Belajar Dan Yang Mempengatuhinya.Jakarta : Rineka Cipta, 2003.

Trianto.Mendesain Model Pembelajaran Inovatif, Progresif dan Kontekstual. Jakarta: PT. Kencana, 2014

Utama Dewi, "Pengaruh Model PBL Terhadap Kemampuan Pemecahan Masalah Fisika Melalui Pengendalian Bakat Numerik siswa Smp", Jurnal, Program Pascasarjana Universitas Pendidikan Ganesha, Vol.4. Jakarta, 2014. 